\title{
A case of lung adenocarcinoma harboring EGFR mutation and EML4-ALK fusion gene
}

\author{
Hisashi Tanaka ${ }^{*}$, Akihito Hayashi', Takeshi Morimoto', Kageaki Taima', Yoshihito Tanaka', Michiko Shimada',
} Akira Kurose $^{2}$, Shingo Takanashi ${ }^{1}$ and Ken Okumura ${ }^{1}$

\begin{abstract}
Background: Lung cancer is the leading cause of cancer-related death worldwide. Epidermal growth factor receptor (EGFR) - tyrosine kinase inhibitor (TKI) is used for the patients with EGFR-mutant lung cancer. Recently, phase III studies in the patients with EGFR-mutant demonstrated that EGFR-TKI monotherapy improved progression-free survival compared with platinum-doublet chemotherapy. The echinoderm microtubule-associated protein-like 4 (EML4) - anaplastic lymphoma kinase (ALK) fusion oncogene represents one of the newest molecular targets in non-small cell lung cancer (NSCLC). Patients who harbor EML4-ALK fusions have been associated with a lack of EGFR or KRAS mutations.

Case presentation: We report a 39-year-old patient diagnosed as adenocarcinoma harboring EGFR mutation and EML4-ALK fusion gene. We treated this patient with erlotinib as the third line therapy, but no clinical benefit was obtained.

Conclusion: We experienced a rare case with EGFR mutation and EML4-ALK. Any clinical benefit using EGFR-TKI was not obtained in our case. The therapeutic choice for the patients with more than one driver mutations is unclear. We needs further understanding of the lung cancer molecular biology and the biomarker infomation.
\end{abstract}

Keywords: Lung cancer, EGFR mutation, EML4-ALK, Erlotinib

\section{Background}

Lung cancer is the leading cause of cancer-related death worldwide. Recent studies on personalized treatment by selecting patients who are likely to respond to a particular therapeutic agent may allow improved treatment efficacy. Patients with non-small cell lung cancer (NSCLC) harboring mutations in the epidermal growth factor receptor $(E G F R)$ gene have dramatic response to the EGFR- tyrosine kinase inhibitor (EGFR-TKI) [1,2]. In 2007, the fusion of the anaplastic lymphoma kinase $(A L K)$ with the echinoderm microtubule-associated protein-like 4 (EML4) was identified in NSCLC. EML4-ALK fusion gene arise as a result of an inversion in chromosome 2 that juxtaposed the 5 end of the EML4 gene with the 3 end of the $A L K$ gene. The frequency of the fusion gene is approximately $6.7 \%$ in NSCLC [3]. The clinical

\footnotetext{
* Correspondence: xyghx335@gmail.com

'Hirosaki University Graduate School of Medicine, Course of Medical Sciences, Cardiology, Respiratory Medicine and Nephrology, Zaifu-cho 5 , Hirosaki 036-8562, Japan

Full list of author information is available at the end of the article
}

features of lung cancer that harbors $E M L 4-A L K$ include light- or never-smokers, younger age, adenocarcinomas with acinar pattern or signet ring adenocarcinoma, and a lack of EGFR or KRAS mutations [4]. Patients who have both mutations are extremely rare.

\section{Case presentation}

A 39-year-old man who is a light-smoker was referred to our hospital in June 2009 because of an abnormal shadow in the left upper field on chest X-ray (Figure 1A). Physical examination revealed no significant abnormalities. Computed tomography (CT) of the chest revealed a $40 \mathrm{~mm}$ tumor in the left $\mathrm{S} 1+2$ with multiple lung and bone metastases (cT4N3M1b). We conducted trans-bronchial lung biopsy (TBLB). The pathological diagnosis of the TBLB specimen was acinar adenocarcinoma (Figure 2A). In immunohistochemistry (IHC) staining, transcription factor1 protein was positive. Laboratory findings were within normal range, except for the carcinoembryonic antigen (CEA) level of $4.7 \mathrm{ng} / \mathrm{mL}$ (normal range, 0 to $4.3 \mathrm{ng} / \mathrm{mL}$ ) in the serum. We made a diagnosis of lung adenocarcinoma and 


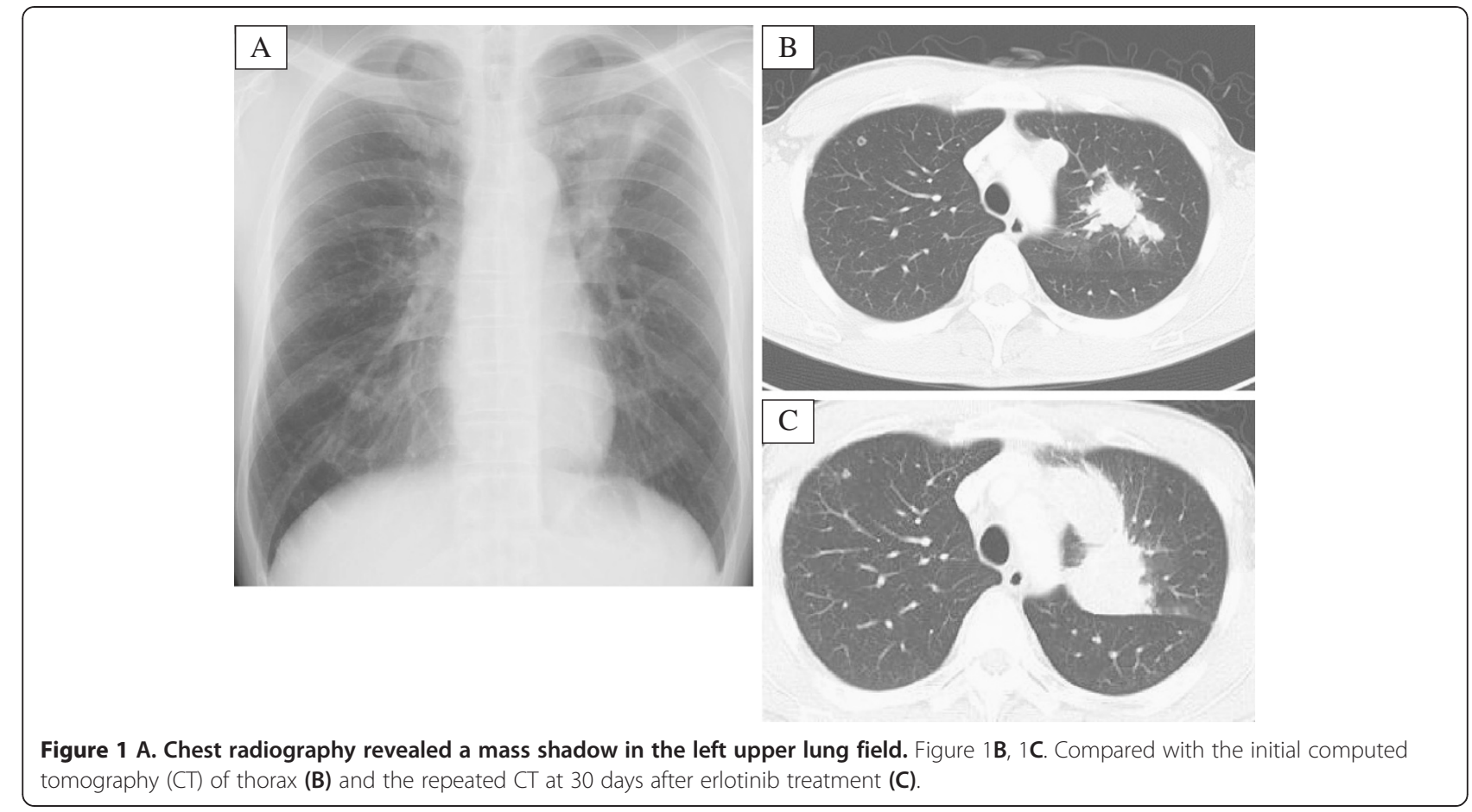

treated the patient with the first line chemotherapy including cisplatin $\left(80 \mathrm{mg} / \mathrm{m}^{2}\right)$ and docetaxel $\left(60 \mathrm{mg} / \mathrm{m}^{2}\right)$ every three weeks up to three cycles. However, no remarkable response was observed. Therefore, the second line chemotherapy was conducted by pemetrexed (PEM) $\left(500 \mathrm{mg} / \mathrm{m}^{2}\right)$ therapy. PEM therapy was effective, and fifteen courses of PEM were administered to the patient. Thereafter new bone metastatic lesions were appeared. The patient had progressive disease (PD). We conducted re-biopsy to the patient to check EGFR mutation analysis by cycleave polymerase chain reaction technique (cycleave-PCR). L858R point mutation (in which leucine at amino acid
858 is replaced by arginine) was detected in the tumor cell (Figure 3). Therefore we treated the patient with erlotinib (150mg) therapy once a day. However, he had disease progression after 30 days (Figure 1B, C). We conducted the second re-biopsy to examine whether the patient had $A L K$ fusion gene. $A L K$ fusion gene was detected by reverse transcription polymerase chain reaction (RT-PCR) method (Figure 4). Additionally, IHC assay using a mouse monoclonal antibody for ALK antibody (Novocastra, Clone 5A4) revealed positive staining (Figure 2B). ALK inhibitor could not be used to the patient because ALK inhibitor was not approved in Japan

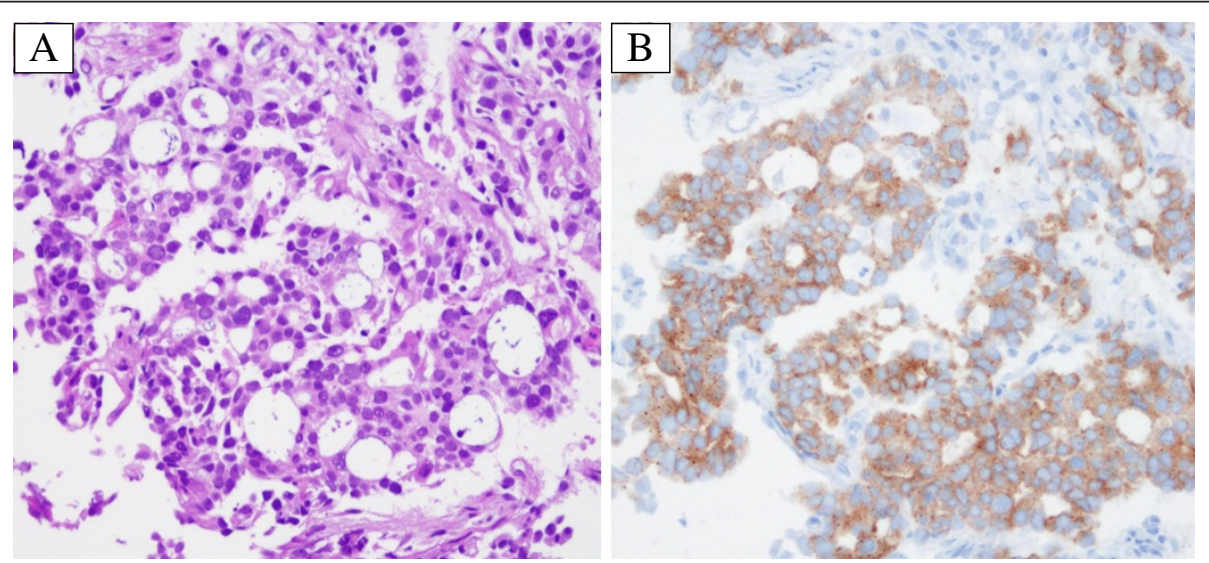

Figure 2 Histology of the primary tumor: (A) well differentiated adenocarcinoma component with acinar pattern (HE $\times 200)$. (B) Immunohistochemical examination revealed that tumor cells were positive for monoclonal anti-ALK antibody (5A4) (×200). 


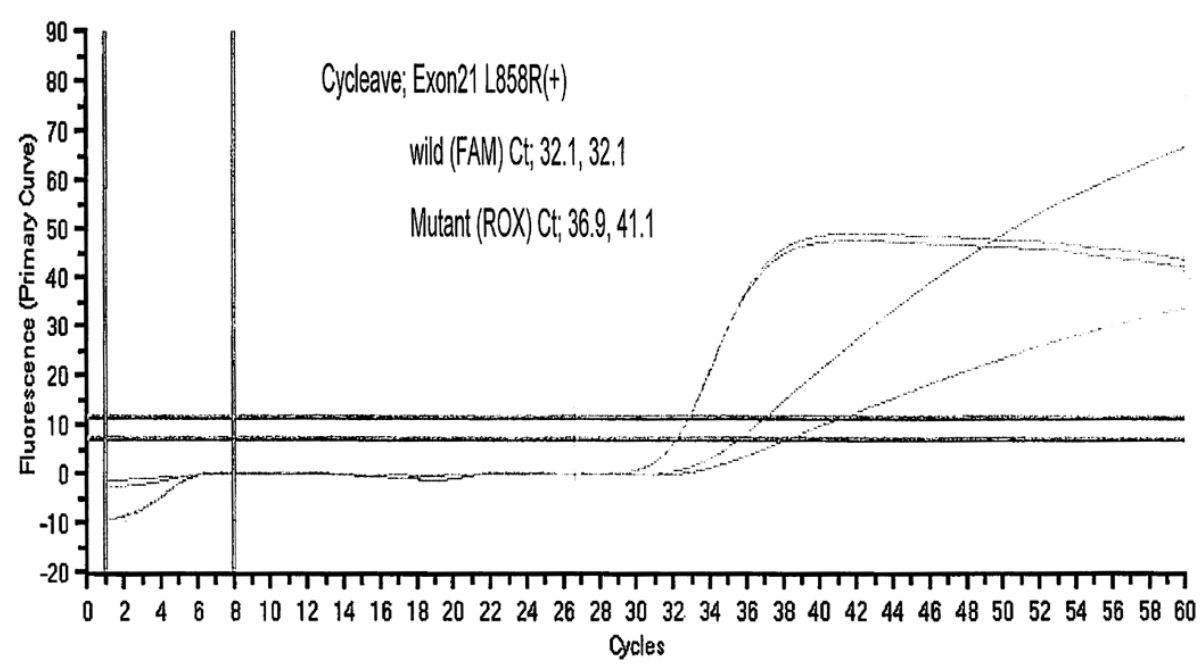

Figure 3 EGFR-gene mutation (L858R point mutation) was showed positive by Cycleave-PCR method.

at that time. The patient was treated fourth line chemotherapy three cycles, the other metastases emerged in his liver, and performance status became 3 , therefore, palliative care was administered to the patient in December 2011.

\section{Discussion}

We experienced a rare case of the patient who had both EGFR mutation and EML4-ALK fusion gene. To the best of our knowledge, five patients with both mutations have been reported so far in the world [5-8]. Four patients received EGFR-TKI therapy (Table 1). Two cases showed good response [5,6], whereas the other two cases did not [7]. We report the 5th case which also did not show good response. In general, the response rate to EGFR-TKI therapy in the patients with EGFR mutation is $70-80 \%$, however, these 5 cases with both mutations tend to be less responsive. In the preclinical study, EML4-ALK positive NSCLC was not responsive to erlotinib therapy [9]. EGFRTKI therapy showed no effects to the all 10 patients with $E M L 4-A L K$ fusion gene [4], although, there were no patients harboring both EGFR mutation and EML4-ALK in these papers. Whereas, EML4-ALK positive patients had a longer progression free survival after PEM therapy compared with EGFR mutant patients [10].

In our case, the characteristics of the patient were young age, light-smoker and acinar pattern adenocaricinoma which showed similarity with the ones of EML4-ALK positive NSCLC. Additionally, PEM therapy showed a good response to our patient, whereas erlotinib therapy did not. In the cases with these both mutations, EML4-ALK gene may play a main role in the oncogenesis for some unknown reasons. Although ALK inhibitor was effective to EML4-ALK positive NSCLC [11], it was not on the market in Japan at that point. Further experience and the understanding of the lung cancer molecular biology are required for the better treatment of the cases with both EGFR mutation and EML4-ALK fusion gene.

\section{Conclusion}

We report a rare case of lung cancer harboring both EGFR mutation and EML4-ALK fusion gene. PEM therapy showed a good response to the patient, whereas erlotinib therapy did not. Oncologists should be aware of the possibility of the multiple mutations.

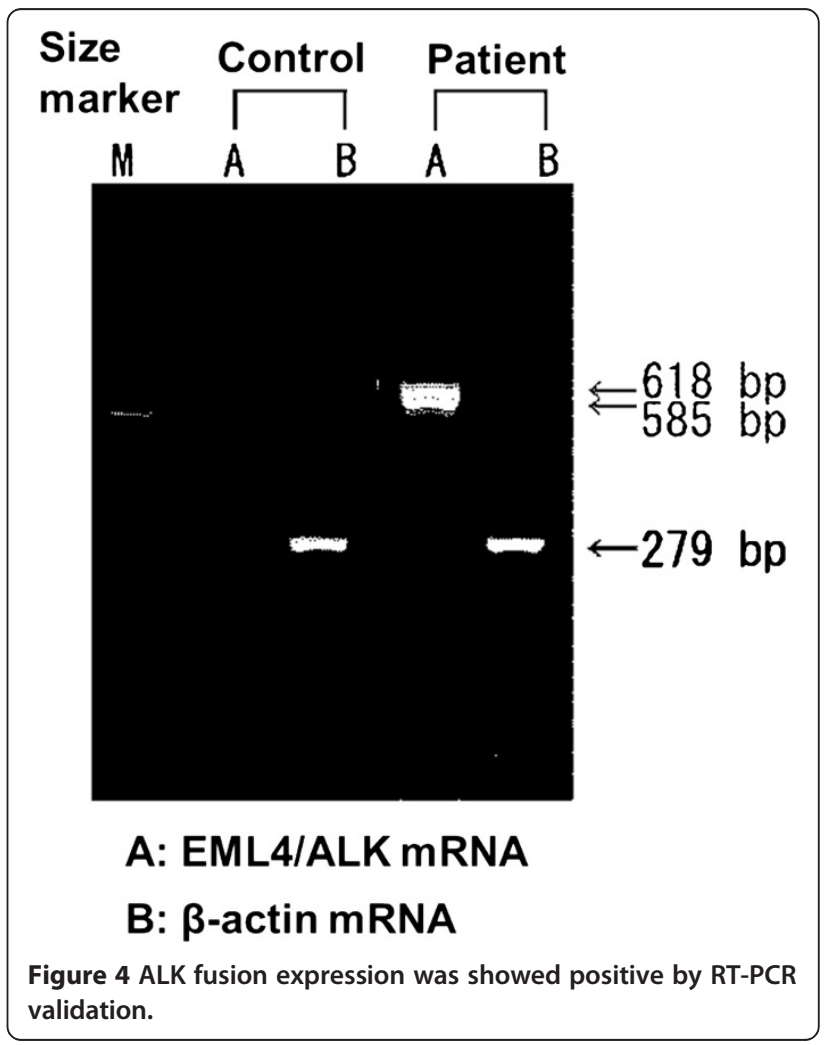


Table 1 Patients characteristics and treatment outcomes by EGFR-TKI

\begin{tabular}{llllllll}
\hline Citation & Age & Sex & Smoking history & Histology & EGFR mutation & EGFR-TKI response & ALK variant \\
\hline Kuo YW, et al. & 72 & Female & Never & Ad & Exon19 deletion & PR & Variant 1 \\
Potat S, et al. & 65 & Female & Never & Ad & Exon19 deletion & CR & Unknown \\
Tiseo M, et al. & 48 & Male & Never & Adsq & Exon19 deletion & PD & Unknown \\
Zhang X, et al. & Unknown & Female & Never & Ad & Exon19 deletion & NA & Variant 3b \\
Present case & 39 & Male & Former & Ad & L858R & PD & Variant 3b \\
\hline
\end{tabular}

Abbreviations.

$A d$ : adenocarcinoma, $A d s q$ : adeno-squamous carcinoma, $C R$ : complete response. $P R$ : partial response, $P D$ : progressive disease, $N A$ : not evaluated.

\section{Consent}

Written informed consent was obtained from the patient for publication of this case report and accompanying images. A copy of the written consent is available for review by the Editor-in-Chief of this journal.

\section{Abbreviations}

EGFR: Epidermal growth factor receptor; TKI: Tyrosine kinase inhibitor; EML4: Echinoderm microtubule-associated protein-like 4; ALK: Anaplastic lymphoma kinase; NSCLC: Non-small cell lung cancer; TBLB: Trans-bronchial lung biopsy; CT: Computed tomography; IHC: Immunohistochemistry: CEA: Carcinoembryonic antigen; PEM: Pemetrexed; PD: Progressive disease; Cycleave-PCR: Cycleave polymerase chain reaction technique; RTPCR: Reverse transcription polymerase chain reaction.

\section{Competing interests}

The authors declare that they have no competing interests.

\section{Authors' contributions}

$H T$ and AH prepared the manuscript and the literature search; KT reviewed and edited the manuscript; TM and MS corrected and revised the manuscript; YT treated and observed the patient; AK performed the histopathological, immunohistochemical examinations; and ST and KO reviewed the manuscript. All authors read and approved the final manuscript.

\section{Author details}

'Hirosaki University Graduate School of Medicine, Course of Medical Sciences, Cardiology, Respiratory Medicine and Nephrology, Zaifu-cho 5, Hirosaki 036-8562, Japan. ${ }^{2}$ Department of Diagnostic Pathology, Hirosaki University Graduate School of Medicine, Hirosaki, Japan.

Received: 27 March 2012 Accepted: 20 November 2012

Published: 26 November 2012

\section{References}

1. Mitsudomi T, Morita S, Yatabe Y, Negoro S, Okamoto I, Tsurutani J, Seto T, Satouchi M, Tada H, Hirashima T, et al: Gefitinib versus cisplatin plus docetaxel in patients with non-small-cell lung cancer harbouring mutations of the epidermal growth factor receptor (WJTOG3405): an open label, randomised phase 3 trial. Lancet Oncol 2010, 11(2):121-128.

2. Maemondo M, Inoue A, Kobayashi K, Sugawara S, Oizumi S, Isobe H, Gemma A, Harada M, Yoshizawa H, Kinoshita I, et al: Gefitinib or chemotherapy for non-small-cell lung cancer with mutated EGFR. $N$ Engl J Med 2010, 362(25):2380-2388

3. Soda M, Choi YL, Enomoto M, Takada S, Yamashita Y, Ishikawa S, Fujiwara S, Watanabe $H$, Kurashina $K$, Hatanaka $H$, et al: Identification of the transforming EML4-ALK fusion gene in non-small-cell lung cancer. Nature 2007, 448(7153):561-566.

4. Shaw AT, Yeap BY, Mino-Kenudson M, Digumarthy SR, Costa DB, Heist RS, Solomon B, Stubbs H, Admane S, McDermott U, et al: Clinical features and outcome of patients with non-small-cell lung cancer who harbor EML4ALK. J Clin Oncol 2009, 27(26):4247-4253.
5. Kuo YW, Wu SG, Ho CC, Shih JY: Good response to gefitinib in lung adenocarcinoma harboring coexisting EML4-ALK fusion gene and EGFR mutation. J Thorac Oncol 2010, 5(12):2039-2040,

6. Popat S, de Vieira Araújo A, Min T, Swansbury J, Dainton M, Wotherspoon A, Lim E, Nicholson AG, O'Brien ME: Lung adenocarcinoma with concurrent exon 19 EGFR mutation and ALK rearrangement responding to erlotinib. J Thorac Oncol 2011, 6(11):1962-1963.

7. Tiseo M, Gelsomino F, Boggiani D, Bortesi B, Bartolotti M, Bozzetti C, Sammarelli G, Thai E, Ardizzoni A: EGFR and EML4-ALK gene mutations in NSCLC: a case report of erlotinib-resistant patient with both concomitant mutations. Lung Cancer 2011, 71(2):241-243.

8. Zhang X, Zhang S, Yang X, Yang J, Zhou Q, Yin L, An S, Lin J, Chen S, Xie Z, et al: Fusion of EML4 and ALK is associated with development of lung adenocarcinomas lacking EGFR and KRAS mutations and is correlated with ALK expression. Mol Cancer 2010, 9:188.

9. Koivunen JP, Mermel C, Zejnullahu K, Murphy C, Lifshits E, Holmes AJ, Choi HG, Kim J, Chiang D, Thomas R, et al: EML4-ALK fusion gene and efficacy of an ALK kinase inhibitor in lung cancer. Clin Cancer Res 2008, 14(13):4275-4283.

10. Camidge DR, Kono SA, Lu X, Okuyama S, Baron AE, Oton AB, Davies AM, Varella-Garcia M, Franklin W, Doebele RC: Anaplastic lymphoma kinase gene rearrangements in non-small cell lung cancer are associated with prolonged progression-free survival on pemetrexed. J Thorac Oncol 2011, 6(4):774-780.

11. Kwak EL, Bang YJ, Camidge DR, Shaw AT, Solomon B, Maki RG, Ou SH, Dezube BJ, Janne PA, Costa DB, et al: Anaplastic lymphoma kinase inhibition in non-small-cell lung cancer. N Eng/ J Med 2010, 363(18):1693-1703.

doi:10.1186/1471-2407-12-558

Cite this article as: Tanaka et al:: A case of lung adenocarcinoma harboring EGFR mutation and EML4-ALK fusion gene. BMC Cancer 2012 12:558.

\section{Submit your next manuscript to BioMed Central and take full advantage of:}

- Convenient online submission

- Thorough peer review

- No space constraints or color figure charges

- Immediate publication on acceptance

- Inclusion in PubMed, CAS, Scopus and Google Scholar

- Research which is freely available for redistribution 